\title{
PARTISIPASI PEMUDA DI TAHUN POLITIK ${ }^{1}$
}

\section{Achmad Zulfikar ${ }^{2}$}

Tahun 2018 dan 2019 merupakan tahun politik. Hal ini ditandai dengan perhelatan politik yang dilaksanakan pada dua tahun yang berentetan ini. Tahun 2018, masyarakat Indonesia akan mengikuti Pemilihan Kepala Daerah Serentak di 171 daerah diantaranya 17 Provinsi, 39 Kota dan 115 Kabupaten se-Indonesia, termasuk diantaranya Provinsi Sulawesi Selatan dan Kota Makassar. Selanjutnya, tahun 2019 warga negara Indonesia di seluruh dunia akan mengikuti Pesta Demokrasi lima tahunan untuk memilih wakil rakyat (DPR) serta Presiden dan Wakil Presiden untuk masa amanah 5 tahun.

Tentu suatu perhelatan akan semarak ketika seluruh elemen bangsa mengambil perannya. Sebut saja pemuda Indonesia yang telah terbukti menjadi motor penggerak perubahan di negeri kita ini. Partisipasi pemuda di tahun politik ini tentu tidak diragukan lagi akan menggerakkan dan menyemarakkan perhelatan Pilkada Serentak maupun Pilpres. Partisipasi ini dapat digolongkan ke dalam partisipasi politik. Partisipasi politik merupakan aspek penting dalam sebuah tatanan negara demokrasi sekaligus merupakan ciri khas adanya modernisasi politik. Di negara-negara yang proses modernisasinya secara umum telah berjalan dengan baik, biasanya tingkat partisipasi politik warga negara meningkat. Modernisasi politik dapat berkaitan dengan aspek politik dan pemerintah.

Partisipasi politik pada dasarnya merupakan kegiatan yang dilakukan warga negara untuk terlibat dalam proses pengambilan keputusan dengan tujuan untuk mempengaruhi pengambilan keputusan yang diambil pemerintah. Istilah "partisipasi politik" telah digunakan dalam berbagai pengertian yang berkaitan dengan perilaku, sikap dan persepsi yang merupakan syarat mutlak bagi partisipasi politik. Herbert McClosky mengemukakan pendapatnya tentang partisipasi politik sebagai: "The term political participation will refer to those voluntary activities by which members of a society share in the selection of rulers and, directly or indirectly, in the formation of public policy" (Partisipasi politik adalah kegiatan-kegiatan sukarela dari warga masyarakat melalui mana mereka mengambil bagian dalam proses pemilihan penguasa, dan secara langsung atau tidak langsung, dalam proses pembentukan kebijakan umum). (Herbert McClosky dalam Miriam Budiarjo, 2015:367)

Definisi yang dikemukakan McClosky tersebut menitikberatkan pada tindakantindakan yang bertujuan untuk mempengaruhi kebijakan-kebijakan pemerintah. Selain itu, hal terpenting yang perlu diperhatikan dalam partisipasi politik yaitu adanya tindakan sukarela dari warga masyarakat tanpa adanya paksaan atau tekanan dari pihak lain. Sedangkan Samuel P. Huntington dan Joan M. Nelson dalam bukunya Partisipasi Politik di Negara Berkembang memaknai partisipasi politik sebagai: "By political participation

\footnotetext{
${ }^{1}$ Naskah ini merupakan versi preprint dari naskah yang sedang dalam proses penerbitan di Majalah Khittah. Publikasi awal naskah ini ditujukan untuk mendapatkan masukan dari publik dan pengembangan khazanah pengetahuan penulis. 2 S.IP., M.Si., M.H. Penulis merupakan Dosen pada Program Studi Ilmu Politik Universitas Hasanuddin. Ia juga mendapat amanah sebagai anggota Bidang Politik dan Kebangsaan pada Pemuda Muhammadiyah Kota Makassar periode 20142018. Ia juga mengabdikan diri pada Makassar Development Institute (MDI) dan Institute of Political and Social Studies (IPOLSS). Penulis dapat dihubungi melalui surel: apa@kabarfikar.com.
} 
we mean activity by private citizens designed to influence government decision-making. Participation may be individual or collective, organized or spontaneous, sustained or sporadic, peaceful or violent, legal or illegal, effective or ineffective". (Partisipasi politik adalah kegiatan warga negara yang bertindak sebagai pribadi-pribadi, yang dimaksud untuk mempengaruhi pembuatan keputusan oleh Pemerintah. Partisipasi bisa bersifat individual atau kolektif, terorganisir atau spontan, mantap atau sporadik, secara damai atau dengan kekerasan, legal atau illegal, efektif atau tidak efektif). (Samuel P. Huntington \&Joan M. Nelson dalam Miriam Budoarjo, 2015:368)

Pada perspektif pengertian yang generik Miriam Budiarjo menyatakan bahwa partisipasi politik secara umum dapat didefinisikan sebagai kegiatan seseorang atau kelompok orang untuk ikut serta secara aktif dalam kehidupan politik, antara lain dengan jalan memilih pemimpin negara dan, secara langsung atau tidak langsung, memengaruhi kebijakan pemerintah (public policy). Kegiatan ini mencakup tindakan seperti memberikan suara dalam pemilihan umum, menghadiri rapat umum, mengadakan hubungan (contacting) atau lobbying dengan pejabat pemerintah atau anggota parlemen, menjadi anggota partai atau salah satu gerakan sosial dengan direct actionnya, dan sebagainya. (Miriam Budiarjo, 2015:367)

Selanjutnya Ramlan Surbakti (2010:180) juga memberikan pengertian yang sejalan dengan pengertian partisipasi politik diatas yakni: partisipasi politik sebagai kegiatan warga negara biasa dalam mempengaruhi proses pembuatan dan pelaksanaan kebijakan umum dan ikut serta menentukan pimpinan pemerintahan. Partisipasi politik tersebut didefinisikan sebagai keikutsertaan warga negara dalam pembuatan dan pelaksanaan kebijakan publik yang dilakukan oleh warga negara biasa.

Berdasarkan beberapa pendapat yang dikemukankan oleh para ahli di atas dapat ditarik kesimpulan bahwa partisipasi politik adalah hal-hal yang berkaitan dengan kegiatan seseorang atau sekelompok orang secara sukarela dalam hal penentuan atau pengambilan kebijakan pemerintah baik itu dalam hal pemilihan pemimpin ataupun penentuan sikap terhadap kebijakan publik yang dibuat oleh pemerintah untuk di jalankan, yang dilakukan secara langsung atau tidak langsung dengan cara konvensional ataupun dengan cara non konvensional atau bahkan dengan kekerasan (violence). Dalam sistem pemerintahan, yang berwenang membuat dan melaksanakan keputusan politik adalah pemerintah, akan tetapi masyarakat mempunyai hak untuk mempengaruhi proses pembuatan serta pelaksanaan keputusan yang dibuat oleh pemerintahan tersebut.

Berdasarkan definisi tersebut partisipasi politik lebih berfokus pada kegiatan politik rakyat secara pribadi dalam proses politik, seperti memberikan hak suara atau kegiatan politik lain yang dipandang dapat mempengaruhi pembuatan kebijakan politik oleh pemerintah dalam konteks berperan serta dalam penyelenggaraan pemerintahan. Dengan demikian partisipasi politik tidak mencakup kegiatan pejabat-pejabat birokrasi, pejabat partai, dan lobbyist professional yang bertindak dalam konteks jabatan yang diembannya.

Selain definisi mengenai partisipasi politik, Milbrath dan Goel, Michael Rush dan Philip Althoff yang dikutip oleh Damsar dalam Pengantar Sosiologi Politik mengidentifikasi bentukbentuk partisipasi politik sebagai suatu tipologi politik. Hirarki tertinggi dari partisipasi politik 
menurut Rush dan Althoff adalah menduduki jabatan politik atau administratif. Sedangkan hierarki yang terendah dari suatu partisipasi politik adalah orang yang apati secara total, yaitu orang yang tidak melakukan aktivitas politik apapun secara total. Semakin tinggi hierarki partisipasi politik maka semakin kecil kuantitas dari keterlibatan orang-orang, seperti yang diperlihatkan oleh bagan hierarki partisipasi politik, dimana garis vertikal segitiga menunjukkan hierarki, sedangkan garis horizontalnya menunjukkan kuantitas dari keterlibatan orang-orang.

Bagan 1. Hierarki Partisipasi Politik

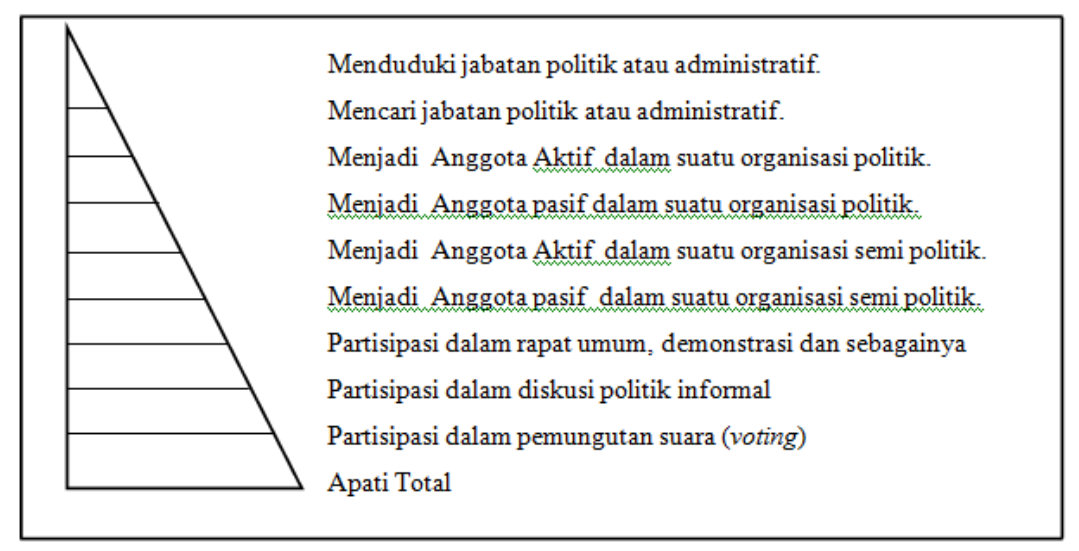

Sumber: Rush dan Althoff (2003) dalam Damsar (2010:185) dan Fadli (2018)

Dari gambaran yang telah dituangkan oleh Rush dan Althoff di atas dapat kita asumsikan bahwa semakin tinggi tingkat atau keinginan suatu masyarakat untuk berpartisipasi dalam kegiatan politik semakin kecil jumlah masyarakat yang terlibat di dalamnya. Namun sebaliknya semakin kebawah tingkatannya semakin kecil peluang masyarakat untuk terlibat aktif dalam kegiatan politik. Apa yang telah dijelaskan Rush dan Althoff dari hirarki tersebut bahwa bentuk partisipasi politik secara umum dan luas serta lebih mudah diamati di lingkungan masyarakat kita ialah pemberian suara pada Pemilu. Partisipasi politik dalam pemberian suatu tersebut ialah dipilih secara langsung anggota DPR/MPR, DPRD, DPD dan presiden dan wakil presiden, serta kepala daerah baik provinsi maupun kabupaten/kota oleh masyarakat. Demokrasi rakyat menempati posisi vital dalam kaitannya dengan pembagian kekuasaan dalam suatu negara (umumnya berdasarkan konsep dan prinsip trias politica) dengan kekuasaan negara yang dipilih oleh rakyat juga harus digunakan untuk kesejahteraan dan kemakmuran rakyat.

Berdasarkan penjelasan mengenai definisi partisipasi politik hingga bentuk-bentuk dan hierarki partisipasi politik, maka partisipasi dengan menggunakan hak pilih pada suatu pemungutan suara (voting) hanya berada satu tingkat di atas orang yang apati total, sedangkan hierarki tertinggi yakni menduduki jabatan politik atau administratif yang tentu saja memerlukan strategi dan keinginan yang kuat untuk memenangkan hati rakyat sebagai pemegang kedaulatan dan pemilih. Apabila kita merefleksikan ke dalam kehidupan keseharian kita, maka tingkatan partisipasi ini telah secara jelas dan terang menunjukkan signifikansi peran pemuda harapan bangsa semakin dibutuhkan dan meningkat. Tentu saja sebagai pemuda yang sadar atas hak pilihnya akan berbondong-bondong mendatangi TPS dan juga mengajak orang-orang terdekatnya untuk menyalurkan hak pilihnya saat hari pemilihan di TPS. 
Ada juga yang telah bergabung sebagai anggota organisasi politik bahkan menjadi tim sukses salah satu kandidat dalam Pilkada maupun Pilpres. Hingga pada tingkatan tertinggi, seseorang menduduki jabatan politik atau administratif. Hal ini ditunjukkan para kandidat Gubernur, Walikota dan Bupati yang masih berada pada rentang usia yang dikategorikan sebagai Pemuda yakni diantara 25-40 tahun. Sebut saja Munafri Arifuddin dan Andi Rachmatika Dewi maupun Muh. Ramdhan Pomanto dan Indira Mulyasari. Keduanya merupakan kandidat yang akan berkompetisi di dalam Pemilihan Walikota dan Wakil Walikota (Pilwalkot) Makassar tahun 2018. Munafri atau dikenal publik dengan sebutan Appi dan Andi Rachmatika Dewi yang dikenal sebagai Cicu merupakan pasangan penantang atas petahana Muh. Ramdhan Pomanto atau lebih umum dikenal Danny Pomanto dan Indira Mulyasari. Kedua pasang calon ini tentu harus menunjukkan komitmen dan kesungguhan untuk memberikan sesuatu yang didambakan oleh warga kota Makassar. Apa itu? Tentu saja bergantung kepentingan individu yang diagregasi menjadi kepentingan publik.

Sebelum mengakhiri tulisan ini izinkan saya untuk mengajak para pembaca, utamanya para pemuda yang mencintai bangsa dan Negara Kesatuan Republik Indonesia (NKRI). Marilah kita renungkan betapa banyak Tuhan Yang Maha Esa memberikan rahmat kepada kita semua sehingga kita dapat menjalankan aktivitas kita dengan aman dan lancar. Menit demi menit waktu yang Anda luangkan di TPS saat Pilkada pada 27 Juni 2018 dan Pilpres pada 17 April 2019 akan menentukan nasib kita semua, rakyat Indonesia untuk masa amanah 5 tahun. Marilah kita beristikharah kepada Maha Penentu untuk mendapatkan petunjuk, calon mana yang terbaik berdasarkan komitmennya bagi kemajuan daerah, bangsa dan negara melalui visi misi yang ditawarkan kepada publik.

Semoga tulisan ini menjadi refleksi bagi kita semua, para pemuda harapan bangsa. Sebagaimana potensi para pemuda Indonesia ini telah disadari sejak dahulu. Bung Karno menegaskan, "Beri aku 10 pemuda dan kita guncang dunia!". Pernyataan tegas ini menekankan bahwa pemuda memiliki peran yang luar biasa hingga dapat mengguncang dunia. Oleh karena itu, marilah para pemuda untuk berpartisipasi aktif di tahun politik ini. $(*)$ 